\title{
Sugar cane treated with calcium hydroxide in diet for cattle: intake, digestibility of nutrients and ingestive behaviour
}

\section{Alexandre Menezes Dias ${ }^{1}$, Luís Carlos Vinhas Ítavo ${ }^{1 *}$, Julio Cesar Damasceno ${ }^{2 *}$, Geraldo Tadeu dos Santos ${ }^{2 *}$, Camila Celeste Brandão Ferreira Ítavo ${ }^{3}$, Fabiano Ferreira da Silva ${ }^{4^{*}}$, Ériklis Nogueira ${ }^{5}$, Cláudia Muniz Soares ${ }^{6}$}

\author{
1 Universidade Católica Dom Bosco - UCDB. Av. Tamandaré, 6000, Jardim Seminário, 79117-900, Campo Grande-MS \\ 2 Universidade Estadual de Maringá - UEM, Maringá-PR. \\ 3 Universidade Federal de Mato Grosso do Sul - UFMS, Campo Grande-MS. \\ 4 Universidade Estadual do Sudoeste da Bahia - UESB, Itapetinga-BA. \\ 5 Embrapa Pantanal, Corumbá-MS. \\ ${ }^{6}$ Doutoranda em Ciência Animal pela UFMS \\ * Bolsista de produtividade do CNPq.
}

\begin{abstract}
The objective of this work was to evaluate, in bovines, the intake and apparent digestibility of nutrients, ingestive behaviour and content of total digestible nutrients (TDN) of diets based on sugar cane treated with calcium hydroxide. It was used four cows with average body weight of $412.06 \mathrm{~kg} \pm 37.3 \mathrm{~kg}$. The study included inclusion of calcium hydroxide at the doses $0,8,16$ and $24 \mathrm{~g} / \mathrm{kg}$ of sugar cane in natural matter basis fed in diets with $65 \%$ of roughage and $35 \%$ on concentrate, based on dry matter $(\mathrm{DM})$. It was used a $4 \times 4$ Latin square experimental design with four treatments and four periods. Calcium hydroxide doses affected nutrient intake: DM intake was $7.88 \mathrm{~kg}$ /day at the dose of $14.99 \mathrm{~g}$ of calcium hydroxide, organic matter (OM) intake was $6.75 \mathrm{~kg} /$ day at $10.94 \mathrm{~g}$; intake of neutral detergent fiber (NDF) of $3.33 \mathrm{~kg} /$ day with a dose of $13.93 \mathrm{~g}$; and intake of acid detergent fiber (ADF) of $2.12 \mathrm{~kg}$ /day with a dose of $10.51 \mathrm{~g}$. Digestibility coefficients showed a quadratic effect for doses of inclusion of calcium hydroxide. Dry matter digestibility was $72.88 \%$ with a dose of $11.65 \mathrm{~g}$ of calcium hydroxide, OM digestibility was $75.12 \%$ with 12.09 g; NDF digestibility was 58.67\% with $12.11 \mathrm{~g}$; ADF digestibility was $52.97 \%$ with $9.36 \mathrm{~g}$ and TDN digestibility was $71.42 \%$ with $10.92 \mathrm{~g}$. There was no effect of the treatment for activities of rumination and total idle. Chewing time, number of bolus chewed and time for rumination of each bolli presented effect. Calcium hydroxide enabled greater intakes and digestibility of nutrients, especially from the cell wall, favoring the use of nutrients from the diet containing sugar cane, recommending a dose of 8-12 g.
\end{abstract}

Key Words: alkaline hydrolysis, chemical treatment, hydrated lime, ruminant nutrition

\section{Introduction}

Sugar cane is a source of roughage in animal feeding. It presents high production per unit of cultivated area, relatively easy cultivation and low cost of production per hectare, better quality and a high DM yield in periods when forage is scarce.

Poor quality roughage is an important source of nutrients which is utilized in ruminant feeding, mainly in under developed countries. The digestibility and intake are the two principal components which determine the feed nutritional value. When high quality diets are provided, the intake of the animal is determined by the energy demand (Ítavo et al., 2002). However, when low-quality diets are provided, the animals intake is at a level that corresponds to the capacity to fill the gastrintestinal tract.

According to Mertens (1993), ruminant digestion is a complex process that involves interactions of microbial population, animal and diet. An alternative for improving the use of sugar cane would be the developing treatments that promote the disruption of the structure of fiber to make it more digestible.

Recently, studies with calcium oxide(Moraes et al., 2008) have pointed out that the hydrolytic treatment did not improve nutrient intake and digestibility of sugar cane for bovines.

Alkaline agents act by turning hemicellulose partly soluble. The phenomenon known as a tumefacient alkaline of cellulose occurs, resulting in cellulose molecule expansion, which causes the rupture of hydrogen bonds, giving the crystallinity of cellulose (Jackson, 1977), which increases the digestion of this hemicellulose. Klopfenstein (1980) reports that the lignin content is not usually modified by chemical treatment, but the action of this treatment leads to an increased rate of fiber digestion.

Understanding animal behavior is fundamental for the development and success of management practices. Other 
factors that need to be considered are behavioral activities, diet and production system, all of them influencing animal performance (Souza et al., 2007).

In this context, the objective of this work was to evaluate the intake on the apparent digestibility and ingestive behavior of bovines fed diets based on sugar cane treated with calcium hydroxide.

\section{Material and Methods}

The work was conducted at the Fazenda Escola São Vicente da Universidade Católica Dom Bosco - UCDB, in Campo Grande, Mato Grosso do Sul, from September to December, 2007.

A forage harvester was used to harvest and to chop sugar cane, which was harvested 14 months after the last cut and chopped into 4-mm pieces.

Four crossbred cows (Angus $\times$ Nellore) fitted with rumen cannula and with an average body weight (BW) of $412.06 \pm 37.3 \mathrm{~kg}$ were confined in individual stalls with a concrete area covering $5 \mathrm{~m}^{2}$ with roof, provided with concrete feeders and drinkers. The cows were fed once daily at 8 a.m., to keep the leftovers that were supplied around 5-10\%. The quantity of sugar cane, concentrate and remains were all recorded daily.

The animals were distributed into a Latin square $(4 \times 4)$ design with four doses of calcium hydroxide $\left(\mathrm{Ca}(\mathrm{OH})_{2}\right)$ (hydrated lime - $\mathrm{CH} \mathrm{I}$ ) and four experimental periods of 21 days, 14 days for animal adaptation to the diets and seven days for data collection. The animals underwent a pre-trial period of 30 days before the start of the experimental phase, to adapt to the diet and management. The animals were weighed at the beginning and end of each experimental period.

Calcium hydroxide was added with doses of 0, 8, 16 and $24 \mathrm{~g}$ per kg natural matter of fresh sugar cane, being calcium hydroxide mixed to the sugar cane before being mixed in concentrate and then supplied to the animals.

Sugar cane was provided after being cut and doses of calcium hydroxide in powder form were added, without diluting with water, according to the treatment, until completely homogenized. Then, roughage was mixed with concentrate and given to the animals (Table 1). Proportion roughage:concentrate of diets (Table 2) was 65:35 on dry matter (DM) basis.

Samples of sugar cane, concentrate and feed leftovers from each animal were collected daily. Composite samples were made per period. Samples of each period were ovendried $\left(55^{\circ} \mathrm{C}, 72\right.$ hours) and grounded to pass through a 1-mm mesh sieve.

Sugar cane samples with and without calcium hydroxide, concentrate, feces and leftovers were composed proportionately to each animal and contents of dry matter (DM), mineral matter (MM), crude protein (CP), ether extract (EE), neutral detergent fiber (NDF) and acid detergent fiber (ADF) were analized as described by Silva \& Queiroz (2002).

Table 1 - Chemical composition of fresh sugar cane and concentrate in the experimental diets

\begin{tabular}{lcc}
\hline Chemical composition & Sugar cane & Concentrate $^{1}$ \\
\hline Dry matter (\%) & 27.43 & 83.70 \\
Organic matter (\% DM) & 96.07 & 91.10 \\
Crude protein (\% DM) & 3.28 & 15.98 \\
Ether extract (\% DM) & 0.05 & 4.84 \\
Neutral detergent fiber, & 48.92 & 31.15 \\
without correction (\% DM) & & \\
Acid detergent fiber (\% DM) & 37.78 & 18.67 \\
Non-fibrous carbohydrate (\% DM) & 43.37 & 39.13 \\
Celullose (\% DM) & 22.74 & nd \\
Lignin (\% DM) & 7.08 & 8.89 \\
Ash (\% DM) & 3.92 & 1.00 \\
Calcium (\% DM) & 0.45 & nd \\
1 Concentrate: 27\% soybean meal; 20\% ground corn; $20 \%$ ground sorghum; $20 \%$ \\
soybean skin; 9\% protected fat; 2\% urea, 2\% mixed mineral; nd = non-determined.
\end{tabular}

Table 2 - Chemical composition of diets based on sugar cane with increasing doses of calcium hydroxide

\begin{tabular}{|c|c|c|c|c|}
\hline \multirow[t]{2}{*}{ Chemical composition } & \multicolumn{4}{|c|}{ Calcium hydroxide (g/kg) } \\
\hline & 0 & 8 & 16 & 24 \\
\hline Dry matter (\%) & 47.12 & 47.82 & 48.38 & 48.87 \\
\hline Crude protein (\% DM) & 7.73 & 7.58 & 7.56 & 7.58 \\
\hline Ether extract $(\%$ DM) & 2.02 & 2.01 & 2.03 & 2.03 \\
\hline Neutral detergent fiber without correction (\% DM) & 42.70 & 42.59 & 42.17 & 41.20 \\
\hline Celullose (\% DM) & 7.08 & 5.88 & 5.22 & 4.74 \\
\hline Lignin (\% DM) & 41.89 & 41.05 & 39.53 & 35.83 \\
\hline Ash (\% DM) & 5.66 & 6.76 & 8.70 & 9.90 \\
\hline
\end{tabular}


Non-fiber carbohydrates (NFC) were calculated by using the equation as recommended by Sniffen et al. (1992): NFC = $100-(\% \mathrm{CP}+\% \mathrm{EE}+\% \mathrm{MM} \%+\mathrm{NDF})$, in which NFC = nonfibrous carbohydrates; $\mathrm{CP}=$ crude protein; $\mathrm{EE}$ = ether extract; $\mathrm{MM}=$ mineral mixture; $\mathrm{NDF}=$ neutral detergent fiber .

When it was tested for apparent digestibility, total fecal collection was conducted during three consecutive days of each experimental period, following the recommendation of Assis et al. (2004). To calculate digestibility (CD), the formula $\mathrm{CD}=(($ intake - excreted $) /$ intake $) \times 100$ was used. The total digestible nutrients (TDN) of diets were determined by Sniffen et al. (1992).

The behavioral assessments were performed in each period, for four periods, in sessions of 24 hours consecutively, starting at 8 a.m., with the feeding of animals, providing fresh feed daily. The collection of quantitative data on the basic patterns of ingestive behavior of cattle, was based on sampling instantaneous scan or rummage (instantaneous scan sampling of behavior status), according to Altmann (1974) and Martin \& Bateson (1993).

To evaluate ingestive behavior, scanning was carried out every five minutes (Penati et al., 1999). Scanning was performed continuously throughout the period of the animal daily activity during 24 hours. During observation, animal activity was recorded on a spreadsheet implemented manually. These observations considered the behavioral activities of feed intake, leisure, rumination and drinking water.

Variables were evaluated by analysis of variance and regression (UFV, 2000) using a 10\% of the probability level for significance.

\section{Results and Discussion}

It was observed that after mixing, doses of calcium hydroxide with fresh sugar cane, the color changed to a yellowish appearance and the odor of the treated sugar cane was altered after being mixed with the alkali agent. A reduction of infestation of bees in feeds treated with calcium hydroxide was also noted. Infestation of bees in the feeds is common in properties that use sugar cane as a source of roughage during the dry season, for supplement or feedlot of bovines, which probably might shorten the feeding time and consequently the nutrient intake of animals.

The quadratic effect for the dose of calcium hydroxide regarding the intake of nutrients $(\mathrm{P}<0.10)$ except for the intake of lignin and ash $(\mathrm{P}>0.10)$ showed a linear effect (Table 3). The inclusion of calcium hydroxide in sugar cane influenced dry matter intake, and by deriving the regression equation adjusted for the dose of calcium hydroxide, it was obtained maximum DM intake of $7.88 \mathrm{~kg}$ /day with $14.99 \mathrm{~g}$ of calcium hydroxide. Calcium hydroxide was mixed into the diet of the animals at feeding time.

The DM intake (DMI) may be considered low in the diets studied, but this was likely due to the effect of filling the gastrointestinal tract because of the forage energy density, due to the low density of forage energy.

Another factor that may have influenced the quadratic response of DMI is related to calcium intake, because when calcium hydroxide is increased, the ash content increased linearly, and consequently, the calcium content increases.

Table 3 - Nutrient intake in kg/day and percentage of body weight (\%BW) of cows fed diets based on sugar cane with doses of calcium hydroxide

\begin{tabular}{|c|c|c|c|c|c|c|c|c|}
\hline \multirow[t]{2}{*}{ Item } & \multicolumn{4}{|c|}{ Calcium hydroxide (g/kg) } & \multirow[t]{2}{*}{ CV (\%) } & \multicolumn{3}{|c|}{$\mathrm{P}$} \\
\hline & 0 & 8 & 16 & 24 & & $\mathrm{~L}$ & Q & $\mathrm{C}$ \\
\hline Dry matter (kg/day) ${ }^{1}$ & 6.44 & 7.77 & 7.69 & 7.45 & 3.24 & 0.0001 & 0.0001 & 0.1629 \\
\hline Organic matter $(\mathrm{kg} / \text { day })^{2}$ & 6.08 & 6.80 & 6.52 & 5.87 & 5.58 & 0.0082 & 0.0021 & 0.3936 \\
\hline Crude protein $(\mathrm{kg} / \text { day })^{3}$ & 0.50 & 0.59 & 0.58 & 0.56 & 3.27 & 0.0002 & 0.0001 & 0.2275 \\
\hline Ether extract (kg/day) ${ }^{4}$ & 0.13 & 0.15 & 0.16 & 0.15 & 3.24 & 0.0000 & 0.0001 & 0.3412 \\
\hline Neutral detergent fiber $(\mathrm{kg} / \mathrm{day})^{5}$ & 2.75 & 3.31 & 3.24 & 3.07 & 3.26 & 0.0008 & 0.0001 & 0.1844 \\
\hline Non-fibrous carbohydrate $\left(\mathrm{kg} /\right.$ day) ${ }^{6}$ & 2.70 & 3.19 & 3.04 & 2.67 & 3.34 & 0.2063 & 0.0001 & 0.4004 \\
\hline Ash $(\mathrm{kg} / \text { day })^{7}$ & 0.35 & 0.44 & 0.55 & 0.78 & 13.91 & 0.0001 & 0.3205 & 0.5309 \\
\hline Dry matter $(\% B W)^{8}$ & 1.57 & 1.88 & 1.89 & 1.80 & 5.33 & 0.0064 & 0.0012 & 0.3341 \\
\hline Organic matter $(\% \mathrm{BW})^{9}$ & 1.48 & 1.65 & 1.60 & 1.42 & 8.25 & 0.3278 & 0.0165 & 0.5432 \\
\hline Neutral detergent fiber $(\% \mathrm{BW})^{10}$ & 0.67 & 0.80 & 0.80 & 0.74 & 5.31 & 0.0306 & 0.0009 & 0.3420 \\
\hline
\end{tabular}

HC = dose calcium hidroxyde $(\mathrm{g}) ; \mathrm{L}=$ linear; $\mathrm{Q}$ = quadratic; $\mathrm{C}=$ cubic; $\mathrm{CV}$ = coefficient of variation.

$1 \hat{Y}=6.500687+0.184048 \times \mathrm{HC}-0.00614053 \times \mathrm{HC}^{2}\left(\mathrm{R}^{2}=0.93\right)$

$2 \hat{\mathrm{Y}}=6.11118+0.117616 \times \mathrm{HC}-0.00537618 \times \mathrm{HC}^{2}\left(\mathrm{R}^{2}=0.96\right)$.

$3 \hat{Y}=0.502634+0.0125188 \times \mathrm{HC}-0.000421686 \times \mathrm{HC}^{2}\left(\mathrm{R}^{2}=0.92\right)$.

$4 \hat{Y}=0.131244+0.00369442 \times H C-0.0001210960 \times H^{2}\left(R^{2}=0.95\right)$.

$5 \hat{Y}=2.77768+0.0798488 \times \mathrm{HC}-0.00286590 \times \mathrm{HC}^{2}\left(\mathrm{R}^{2}=0.93\right)$.

$6 \hat{\mathrm{Y}}=2.72058+0.0779016 \times \mathrm{HC}-0.00337170 \times \mathrm{HC}^{2}\left(\mathrm{R}^{2}=0.99\right)$.

$7 \hat{Y}=0.318952+0.174882 \times \mathrm{HC}\left(\mathrm{r}^{2}=0.95\right)$.

$8 \hat{Y}=1.57686+0.0462687 \times \mathrm{HC}-0.00155189 \times \mathrm{HC}^{2}\left(\mathrm{R}^{2}=0.97\right)$

$9 \hat{\mathrm{Y}}=1.488183+0.0303727 \times \mathrm{HC}-0.00137994 \times \mathrm{HC}^{2}\left(\mathrm{R}^{2}=0.99\right)$.

$10 \hat{\mathrm{Y}}=0.673159+0.0200473 \times \mathrm{HC}-0.000721179 \times \mathrm{HC}^{2}\left(\mathrm{R}^{2}=0.97\right)$. 
Deriving the equation of regression of organic matter (Table 3) to meet the maximum intake $(6,75 \mathrm{~kg} /$ day) of organic matter it is necessary to add $10.94 \mathrm{~g}$ of calcium hydroxide. This variable is important because when you increase the dose of calcium hydroxide, the ash content is increased, characterizing the effect of hydrolysis due to the influence of calcium hydroxide, increasing intake of OM.

Moraes et al. (2008) reported that the application of calcium oxide in sugar cane decreased the intake of all nutrients. This loss may have been the result of a high temperature $\left(10 \mathrm{~g} / \mathrm{kg}\right.$ rises $\left.0.5^{\circ} \mathrm{C} / \mathrm{hour}\right)$ of sugar cane with calcium oxide as compared to fresh cane sugar. However, the use of calcium hydroxide as an additive, avoid the internal temperature of the material rising, favoring the intake of nutrients.

It must be considered that the provision of degradable nitrogen, for the rumen microorganisms, affect DM intake. A deficiency or an excess of rumen degradable protein leads to a reduction in intake by impairing the activity of cellulolytic bacteria or generates excessive production of ammonia, respectively, with consequences on motility and ruminal fermentation. This effect can alter patterns of fermentation and the rate of the passage of fiber and consequently the rate of passage through the gastrointestinal tract. The contribution of dietary CP was $7 \%$ to maintain the functioning of the rumen by means of effective microbial growth (van Sest, 1994).

According to Van Soest (1994), CP concentrations above $7 \%$ does not influence intake, but there is a reduction in DM intake when using diets with less than 7\% CP in total DM, which was confirmed in a study conducted by Valadares et al. (1997). These authors, using diets containing 7, 9.5, 12 and $14.5 \% \mathrm{CP}$ in DM, observed that diets containing 7\% CP had lower DMI than the others, which did not differ. Also, Ítavo et al. (2002) found that DM intake was expressed as a percentage of $\mathrm{BW}$, from Nelore in the growing phase, a diet containing 14\% CP was 9.17\% lower than the intake recorded for the diet with $17 \% \mathrm{CP}$.

Doses of calcium hydroxide affected $(\mathrm{P}<0.10)$ NDF intake (Table 4), and they were below the average described by Mertens (1992), which is $1.2 \%$ of BW. Average for the NDF intake was $0.75 \% \mathrm{BW}$. Three cows were in the middle of pregnancy during the experiment. At this stage of pregnancy, usually in bovines, intake is controlled by physical mechanisms, because of the increased fetal growth by decreasing the rumen which compresses the space for food intake, which may influence the DM and NDF, and because the NDF content of the sugar cane, it was caused by reduced intake, due to rumen fill.

The maximum level for NDF intake (3.33 kg/day) with $3.93 \mathrm{~g}$ calcium hydroxide was obtained. This dose increased the DM and OM, reflecting in NDF intake, characterizing the effect of hydrolysis provided by calcium hydroxide.

The increased dose of calcium hydroxide was effective for the ADF content (Table 2). It is related to the effect of hydrolysis of calcium hydroxide in the fiber of sugar cane, characterizing the partial soluble of hemicellulose, consisting of expansion of the cellulose molecules, causing a rupture of hydrogen bonds. The maximum found by deriving the regression equation of ADF intake was $2.12 \mathrm{~kg} /$ day with $10.51 \mathrm{~g}$ of calcium hydroxide.

There was a quadratic effect on apparent digestibility ( $\mathrm{P}<0.10$ ) of all nutrients (Table 4$)$. The maximum dry matter digestibility (72.88\%) occurred at $11.65 \mathrm{~g} / \mathrm{kg}$ of calcium hydroxide.

Dose of $8 \mathrm{~g} / \mathrm{kg}$ increased by $6.84 \%$ for DM compared with dose $0 \mathrm{~g} / \mathrm{kg}$, which was consistent with Oliver et al. (2008), who found that after three hours of treatment with hydrated lime, there was a significant difference in average in vitro dry matter digestibility , with increases of 4.78 and

Table 4 - Nutrient digestibility and total digestible nutrients (TDN) of diets based on sugar cane with calcium hydroxide

\begin{tabular}{|c|c|c|c|c|c|c|c|c|}
\hline \multirow[t]{2}{*}{ Item } & \multicolumn{4}{|c|}{ Calcium hydroxide (g/kg) } & \multirow[t]{2}{*}{ CV (\%) } & \multicolumn{3}{|c|}{$\mathrm{P}$} \\
\hline & 0 & 8 & 16 & 24 & & $\mathrm{~L}$ & Q & $\mathrm{C}$ \\
\hline Dry matter $(\%)^{1}$ & 65.30 & 72.14 & 71.84 & 64.39 & 3.76 & 0.1334 & 0.0136 & 0.4289 \\
\hline Organic matter $(\%)^{2}$ & 65.68 & 78.18 & 73.27 & 65.99 & 3.19 & 0.1609 & 0.0104 & 0.2908 \\
\hline Crude protein $(\%)^{3}$ & 44.51 & 66.34 & 64.36 & 52.57 & 10.56 & 0.0876 & 0.0382 & 0.5790 \\
\hline Ether extract $(\%)^{4}$ & 65.78 & 77.47 & 77.18 & 63.89 & 7.73 & 0.3201 & 0.0831 & 0.3991 \\
\hline Non-fibrous carbohydrate $(\%)^{5}$ & 93.99 & 95.03 & 94.53 & 92.08 & 0.35 & 0.0908 & 0.0328 & 0.2288 \\
\hline Neutral detergent fiber $(\%)^{6}$ & 39.03 & 68.63 & 56.26 & 41.84 & 9.29 & 0.2409 & 0.0088 & 0.3493 \\
\hline Total digestible nutrients $(\%)^{7}$ & 65.23 & 74.89 & 68.88 & 61.10 & 3.38 & 0.1508 & 0.0113 & 0.4028 \\
\hline
\end{tabular}

$\mathrm{HC}=$ dose of calcium hydroxide $(\mathrm{g}) ; \mathrm{L}=$ linear; $\mathrm{Q}=$ quadratic; $\mathrm{C}=$ cubic; $\mathrm{CV}=$ coefficient of variation.

$1 \hat{Y}=65.3164+1.2971 \times \mathrm{HC}-0.0556471 \times \mathrm{HC}^{2}\left(\mathrm{R}^{2}=0.89\right)$

$2 \hat{Y}=67.3310+1.28826 \times \mathrm{HC}-0.0532575 \times \mathrm{HC}^{2}\left(\mathrm{R}^{2}=0.88\right)$

$3 \hat{Y}=47.0692+1.88609 \times \mathrm{HC}-0.0590284 \times \mathrm{HC}^{2}\left(\mathrm{R}^{2}=0.97\right)$

$4 \hat{Y}=67.6496+1.121551 \times \mathrm{HC}-0.049489 \times \mathrm{HC}^{2}\left(\mathrm{R}^{2}=0.99\right)$.

$\hat{Y}=97.2092+0.412146 \times \mathrm{HC}-0.0158033 \times \mathrm{HC}^{2}\left(\mathrm{R}^{2}=0.88\right)$

${ }^{6} \hat{\mathrm{Y}}=41.1879+2.8871 \times \mathrm{HC}-0.119190 \times \mathrm{HC}^{2}\left(\mathrm{R}^{2}=0.93\right)$

$7 \hat{Y}=65.2357+1.13187 \times$ HC $-0.0518127 \times H^{2}\left(R^{2}=0.87\right)$. 
$6.47 \%$ at doses 5 and $6 \mathrm{~g} / \mathrm{kg}$ of calcium hydroxide for the dose without calcium hydroxide, respectively. This demonstrates that the hydrolysis occurred sharply.

Alves et al. (2001) reached increases of 8.6 and 3.3\% in the digestibility of $\mathrm{CP}$ in the diet when sugar cane was hydrolyzed with 2 or $4 \% \mathrm{NaOH}$, and the diets were composed of hydrolyzed sugar cane and 2 kg concentrate/ day, similar to that used in this work. Maximum CP digestibility (62.14\%) $15.98 \mathrm{~g}$ of calcium hydroxide was obtained, when it derived from the fitted regression equation (Table 4).

Moraes et al. (2008) found no effect of the treatment with sugar cane with $1 \%$ calcium oxide on the digestibility of nutrients. This contradicts the principle of alkaline hydrolysis, the phenomenon known as swelling of the alkali cellulose, which causes an expansion and rupture of the cellulose molecules, which would improve the utilization of the feed by the rumen microorganisms, a factor that may have occurred in this study, showing higher values in the digestibility and in the NDF intake.

Digestibility of fiber was increased $(\mathrm{P}<0.10)$, probably because of a hydrolysis effect on the fibrous fraction, caused by adding calcium hydroxide at the doses between $8-16 \mathrm{~g} / \mathrm{kg}$. Another important variable is the digestibility of hemicellulose, as calcium hydroxide had the highest effect, resulting in higher solubilization of hemicellulose reaching the maximum point (72.42\%) and $14.77 \mathrm{~g}$ of calcium hydroxide was obtained.

The breaking of ester bonds between lignin and the fibrous carbohydrates, due to the $\mathrm{pH}$ increase, by alkaline hydrolysis, allows a greater action of microbial enzymes, resulting in disruption of cell wall structure, causing an increase in its hydration. Another effect related to the ability of calcium hydroxide is that it forms a complex with cellulose, reducing its crystallinity, through the breaking up of hydrogen bonds, increasing its fragility and providing better enzymatic digestion. The combination of these factors causes faster fragmentation of the ingested material and improves the efficiency of microbiota ruminal.
According to Klopfenstein (1980), the lignin content is not usually modified by chemical treatment, but by doing it, rate of fiber digestion increases. The effect of lignification in digestibility of cell wall explains quantitatively the influence of total lignin in DMS. Consequently, many taxonomic variations of the quantitative relationship between lignin and digestibility can be explained by the contents of the cell wall. Contrary to Van Soest (1994), it was highlighted the effect of alkaline products on the fiber fraction of forages of low nutritional value, and noted that the fraction of lignin can be solubilized with high concentrations of $\mathrm{NaOH}$.

Maximum point showed for NDF digestibility of 12.11 $\mathrm{g} / \mathrm{kg}$ of calcium hydroxide. Similarly, Oliver et al. (2008) reported that treatment with $5 \mathrm{~g} / \mathrm{kg}$ of calcium oxide improved the in vitro digestibility of DM and NDF.

A significant improvement in the digestibility of sugar cane treated with calcium hydroxide was observed, emphasizing the alkaline effect on roughage acquired with this treatment, which can offer security and stability in ruminant feed.

The doses presented an effect $(\mathrm{P}<0.10)$ in the intake of total digestible nutrients (TDNI) (Table 5). The values for obtaining the maximum of the variables NDT (71.42\%) and TDNI (5.71 kg/day) $10.92 \mathrm{~g}$ and $12.36 \mathrm{~g}$, respectively. Thus, these results are in agreement with Kozloski (2002), who cited that microbial growth is regulated by the availability of limiting nutrients or growth factors.

TDN intake may be related to the increase in OM intake, whereas the TDN is a measure that represents the summation of all the digestible nutrients in the feeds and also expresses energy, the dietary $\mathrm{CP}$ amount can influence the NDT intake. Mlay et al. (2003) suggested that a decrease in intake and digestibility of tropical grasses was caused by the low levels of nitrogen and availability of ammonia for cellulolytic bacteria of rumen.

The doses had no effect $(\mathrm{P}>0.10)$ on the time spent on feeding, as well as the activities of water intake (Table 6) allocating $1.27 \%$ of daily activities for drinking water. By

Table 5 - Intake of total digestible nutrients (TDNI) in kg/day and percentage of body weight (\%BW) of cows fed diets based on sugar cane with doses of calcium hydroxide

\begin{tabular}{|c|c|c|c|c|c|c|c|c|}
\hline \multirow[t]{2}{*}{ Item } & \multicolumn{4}{|c|}{ Calcium hydroxide (g/kg) } & \multirow[t]{2}{*}{ CV (\%) } & \multicolumn{3}{|c|}{$\mathrm{P}$} \\
\hline & 0 & 8 & 16 & 24 & & $\mathrm{~L}$ & $\mathrm{Q}$ & C \\
\hline TDN kg/day ${ }^{1}$ & 4.20 & 5.82 & 5.30 & 4.55 & 0.65 & 0.0943 & 0.0001 & 0.4309 \\
\hline TDN $(\% B W)^{2}$ & 1.02 & 1.41 & 1.30 & 1.10 & 5.78 & 0.0502 & 0.0001 & 0.2109 \\
\hline TDN $\left(\mathrm{BW}^{0,75}\right)^{3}$ & 46.05 & 63.42 & 58.44 & 49.67 & 4.34 & 0.1802 & 0.0001 & 0.3309 \\
\hline
\end{tabular}

$\mathrm{HC}=$ dose calcium hidroxyde (g); NDF = neutral detergent fiber; $\mathrm{NFC}=$ non-fibrous carbohydrate; TDN = total digestible nutrients; $\mathrm{L}=$ linear; $\mathrm{Q}=$ quadratic; $\mathrm{C}=$ cubic $\mathrm{CV}=$ coefficient of variation.

$1 \hat{Y}$ TDNI (kg/day) $=4.29668+0.228179 \times \mathrm{HC}-0.00923071 \times \mathrm{HC}^{2}\left(\mathrm{R}^{2}=0.88\right)$.

$2 \hat{\mathrm{Y}}$ TDNI $(\% \mathrm{BW})=1.04293+0.0562753 \times \mathrm{HC}-0.00227665 \times \mathrm{HC}^{2}\left(\mathrm{R}^{2}=0.92\right)$.

$3 \hat{\mathrm{Y}}{ }_{\mathrm{TDNI}}^{\mathrm{TDN}}(\mathrm{BW}, \mathrm{BW})=46.9782+2.52388 \times \mathrm{HC}-0.102104 \times \mathrm{HC}^{2}\left(\mathrm{R}^{2}=0.91\right)$. 
assessing the total time spent on resting, the animals were subjected to a dose of $24 \mathrm{~g} / \mathrm{kg}$, showing the highest mean ( $P=0.06086$ ), accounting for $63.56 \%$ of daily activity. These animals showed a lesser average of 337.16 minutes (19.92\% of daily activity).

The dose with $24 \mathrm{~g} / \mathrm{kg}$ showed the greatest activity of resting $(\mathrm{P}<0.10)$, being higher than dose $0 \mathrm{~g} / \mathrm{kg}$ and equal to the doses 8 and $16 \mathrm{~g} / \mathrm{kg}$, probably because of a decrease in NDF content in the diet (Table 2), according to increasing doses of calcium hydroxide.

The animals that received calcium hydroxide spent more time in rumination, spending about seven hours and 47 minutes with rumination activities, probably due to less digestible NDF.

Ruminants like any other species, seek to adjust feed intake to fit their nutritional needs, especially energy (Arnold, 1985). Housed animals spent around one hour consuming energy-rich feed rich in energy, or more than six hours, with low energy-content feed. Also, the time spent with ruminating is influenced by the nature of the diet and, probably, it is proportional to the cell wall content of roughage (Van Soest, 1994).

According to Van Soest (1994), concentrate feed and hay are finely ground and or made into pellets because this type of feed reduces rumination time, whereas roughage with a high content of cell walls tends to increase rumination time. The increase of intake reduces rumination time. The cell wall content was influenced by calcium hydroxide, which allowed the fiber components to be more available, thus reducing the time spent in rumination, as demonstrated by the ADF and hemicellulose content (Table 2).
The doses of calcium hydroxide influenced $(\mathrm{P}<0.10)$ the ingestive behavior of cows and time spent ruminating and resting, the time spent on feed intake was similar for all doses. However, it has to be noted that the average time spent/bolus was influenced by the dose of calcium hydroxide in the fresh sugar cane.

The time spent ruminating is longer during the night, but it is also influenced by the diet. However, there are differences among the animals, which are the length of time, the distribution of activities, eating and rumination. All of which seem to be related to the appetite of animals, anatomical differences and energy supplement requirements or and rumen fill (Souza et al., 2007).

Rumination time is highly correlated (0.96) with NDF intake in cattle (Welch, 1982). Albright (1993), in experiments with cows, reported three levels of NDF in the diets (26, 30 and $34 \%$ ), a quadratic effect with maximum values, the time spent in rumination and total chewing 344 and 558; 403 and 651, and 414 and $674 \mathrm{~min} /$ day respectively.

The number of chews per bolus (NCB) was affected by the doses (Table 7), showing a quadratic effect $(\mathrm{P}<0.10)$. Fischer et al. (1997) reported that animals which have a higher feed intake presented a smaller number of ruminal bolus and shorter chewing time per bolus (CTB).

By deriving the regression equation adjusted for the NCB, $18.66 \mathrm{~g} / \mathrm{kg}$ of calcium hydroxide to a smaller value of chewing (43.16) was obtained. This value coincides with the maximum values of DMI. Thus, the use of alkalizing additives, in order to partially hydrolyze fibrous fractions of the cell wall, can positively influence feeding behavior of ruminants.

Table 6 - Time (in minutes spent) and ingestive behavior of cows in function of the dose of calcium hydroxide

\begin{tabular}{|c|c|c|c|c|c|c|c|c|}
\hline \multirow[t]{2}{*}{ Item } & \multicolumn{4}{|c|}{ Calcium hydroxide (g/kg) } & \multirow[t]{2}{*}{ CV (\%) } & \multicolumn{3}{|c|}{$\mathrm{P}$} \\
\hline & 0 & 8 & 16 & 24 & & $\mathrm{~L}$ & $\mathrm{Q}$ & $\mathrm{C}$ \\
\hline Feeding & 215.00 & 215.00 & 201.67 & 221.67 & 22.53 & 0.4389 & 0.4567 & 0.4908 \\
\hline Total rumination ${ }^{1}$ & 448.66 & 404.83 & 361.00 & 317.16 & 25.03 & 0.0690 & 0.2453 & 0.3809 \\
\hline Water intake & 23.33 & 15.00 & 16.67 & 18.33 & 51.02 & 0.3564 & 0.2908 & 0.3390 \\
\hline Total resting ${ }^{2}$ & 788.67 & 833.17 & 877.67 & 922.17 & 14.10 & 0.0608 & 0.3209 & 0.5643 \\
\hline
\end{tabular}

$\mathrm{HC}=$ dose calcium hidroxyde (g); $\mathrm{CV}=$ coefficient of variation.

${ }^{1} \hat{Y}=418.667-5.47917 \times \mathrm{HC}\left(\mathrm{r}^{2}=0.73\right)$

$2 \hat{Y}=803.437+2.12889 \times \mathrm{HC}\left(\mathrm{r}^{2}=0.78\right)$

Table 7 - Number chewing/bolus ruminated (NCB), chewing time per bolus (TCB) in seconds in function of calcium hydroxide dose

\begin{tabular}{|c|c|c|c|c|c|c|c|c|}
\hline \multirow[t]{2}{*}{ Item } & \multicolumn{4}{|c|}{ Calcium hydroxide (g/kg) } & \multirow[t]{2}{*}{ CV (\%) } & \multicolumn{3}{|c|}{$\mathrm{P}$} \\
\hline & 0 & 8 & 16 & 24 & & $\mathrm{~L}$ & $\mathrm{Q}$ & C \\
\hline $\mathrm{NCB}^{1}$ & 59.75 & 43.92 & 47.67 & 48.00 & 17.49 & 0.1601 & 0.0281 & 0.3409 \\
\hline СТВ (sec/bolus) ${ }^{2}$ & 62.92 & 42.08 & 48.08 & 49.02 & 15.84 & 0.1908 & 0.0008 & 0.1543 \\
\hline
\end{tabular}

HC = dose calcium hidroxyde $(\mathrm{g}) ; \mathrm{L}=$ linear; $\mathrm{Q}=$ quadratic; $\mathrm{C}=$ cubic $\mathrm{CV}=$ coefficient of variation.

$1 \hat{\mathrm{Y}}=58.3500-1.62812 \times \mathrm{HC}+0.0436197 \times \mathrm{HC}^{2}\left(\mathrm{R}^{2}=0.78\right)$

$2 \hat{Y}=61.0417-2.17187 \times \mathrm{HC}+0.063151 \times \mathrm{HC}^{2}\left(\mathrm{R}^{2}=0.74\right)$ 
These reports are in agreement with Fischer et al. (1997), who observed that animals which presented a higher feed intake had fewer ruminal bolus and lower TCB. Silva et al. (2005) found a decreasing linear effect whose values were 44, 44, 43 and 37 chews per bolus at levels of $0.25 \%$, $0.50 \%, 0.75 \%$ and $1.00 \%$ of supplementation of live weight of grazing heifers, when the level of supplementation of animals was raised, this reduced the fiber content in the diet and also TCB. Sugar cane without calcium hydroxide provided the highest $\mathrm{NCB}(\mathrm{P}<0.10)$, whereas, when it was added to calcium hydroxide, the values of NCB were reduced.

Miranda et al. (1999) evaluated the feeding behavior of dairy heifers fed diets based on sugar cane and found no difference in time spent eating, ruminating and total chewing time, in minute/day for heifers fed different sources of NPN and probiotics.

Nutritional value of forage can be improved by using calcium hydroxide which can be used based on the cost of application and economic return. Another possible factor to improve the intake and digestibility of nutrients could be carried out by increasing the concentrate in the animals diet.

\section{Conclusions}

The treatment of sugar cane with calcium hydroxide provides better intake and higher digestibility of nutrients, especially the fiber fraction. It is recommended the dose of about $12 \mathrm{~g}$ calcium hydroxide per $\mathrm{kg}$ of fresh sugar cane for bovines feed.

\section{References}

ASSIS, A.J.; CAMPOS, J.M.S.; QUEIROZ, A.C. et al. Polpa cítrica em dietas de vacas em lactação. 2. Digestibilidade dos nutrientes em dois períodos de coleta de fezes, ph e nitrogênio amoniacal do líquido ruminal. Revista Brasileira de Zootecnia, v.33, n.1, p.251-257, 2004.

ALBRIGHT, J.L. Feeding behavior of dairy cattle. Journal of Dairy Science, v.76, n.2, p.485-498, 1993.

ALTMANN, J. Observational study of behavior sampling methods. Behaviour, v.49, p.227-267, 1974.

ARNOLD, G.W. Ingestive behavior. In: FRASER, A.F. (Ed.) Ethology of farm animals. Amstrerdam: Elsevier, 1985. $186 p$.

BERGER, L.L.; FAHEY, G.C; BOURQUIN, L.D. et al. Modification of forage after harvest. In: FAHEY, D.C. (Ed.) Forage quality, evaluation, and utilization. Madison: American Society of Agronomy, Crop Science Society, Soil Science Society, 1994. p.922-966.

FISCHER, V.; DESWYSEN, A.G.; DÈSPRES, L. et al. Comportamento ingestivo de ovinos recebendo dieta à base de feno durante um período de seis meses. Revista Brasileira de Zootecnia, v.26, n.5, p.1032-1038, 1997.
ÍTAVO, L.C.V.; VALADARES FILHO, S.C.; SILVA, F.F. et al. Consumo, degradabilidade ruminal e digestibilidade aparente de fenos de gramíneas do gênero Cynodon e rações concentradas utilizando indicadores internos. Revista Brasileira de Zootecnia, v.31, n.2, p.1024-1032, 2002.

JACKSON, M.G. Review articles: the alkali treatment of straws. Animal Feed Science and Technology, v.2, n.2, p.105-130, 1977.

KLOPFERNSTEIN, T. Chemical treatment of crop residues. Journal of Animal Science, v.46, n.3, p. 841-849, 1980.

KOZLOSKI, G.V. Bioquímica dos ruminantes. Santa Maria: UFSM, 2002. 140p.

LEÃO, M.I.; VALADARES FILHO, S.C.; RENNÓ, L.N. et al. Consumos e digestibilidades totais e parciais de carboidratos totais, fibra em detergente neutro e carboidratos não fibrosos em novilhos submetidos a três níveis de ingestão e duas metodologias de coleta de digestas abomasal e omasal. Revista Brasileira de Zootecnia, v.34, n.2, p.670-678, 2005.

MARTIN, P.; BATESON, R. Measuring behaviour. Cambridge: Cambridge University Press, 1993. p.84-100.

MERTENS, D.R. Analysis of fiber in feeds and its uses in feed evaluation and formulation. In: REUNIÃO ANUAL DA SOCIEDADE BRASILEIRA DE ZOOTECNIA, 29, 1992, Lavras. Anais... Lavras: SBZ, 1992. p.1-32.

MERTENS, D.R. Qualitative aspect of ruminant digestion and metabolism. In: FORBES, J.M.; FRANCE, J. (Eds.) Rate and extent of digestion. Wisconsin: CAB, 1993. p.13-51.

MIRANDA, L.F.; QUEIROZ, A.C.; VALADARES FILHO, S.C. et al. Comportamento ingestivo de novilhas leiteiras alimentadas com dietas à base de cana-de-açúcar. Revista Brasileira de Zootecnia, v.28, n.3, p.614-620, 1999.

MLAY, P.S.; PEREKA, A.E. WEISBJERG, M. R. et al. Digestion and passage kinetics of fibre in mature dairy heifers maintained on poor quality hay as affected by the source and level of nitrogen supplementation. Animal Feed Science and Technology, n.109, p.19-33, 2003.

MORAES, K.A.K.; VALADARES FILHO, S.C.; MORAES, H.B.K. et al. Cana-de-açúcar tratada com óxido de cálcio fornecida com diferentes níveis de concentrado para novilhas de corte em confinamento. Revista Brasileira de Zootecnia, v.37, n.7, p.1293-1300, 2008.

NATIONAL RESEARCH COUNCIL - NRC. Nutrient requirements of dairy cattle. 7.ed. Washington, D.C.: National Academy Press, 2001. 381p.

PENATI, M.A.; CORSI, M.; MARTHA JR, G.B. et al. Manejo de plantas no pastejo rotacionado. In: SIMPÓSIO GOIANO SOBRE PRODUÇÃO DE BOVINOS DE CORTE, 11., 1999, Goiânia. Anais... Goiânia: CBNA, 1999. p.123-144.

OLIVEIRA, M.D.S.; SANTOS, J.; DOMINGUES, F.N. et al. Avaliação da cal hidratada como agente hidrolisante de canade-açúcar. Veterinária Notícias, v.14, n.1, p.9-17, 2008.

ØRSKOV, E.R. Alimentación de los ruminates. Princípios y práctica. Zaragoza: Acribia, 1990. 119p.

SILVA, D.J.; QUEIROZ, C.A. Análise de alimentos: métodos químicos e biológicos. Viçosa, MG: Universidade Federal de Viçosa, 2002. 235p.

SILVA, J.F.C.; LEÃO, M.I. Fundamentos de nutrição de ruminantes. Piracicaba: Livroceres, 1979. 380p.

SILVA, R.R; CARVALHO, G.G.P; MAGALHÃES, A.F. et al. comportamento ingestivo de novilhas mestiças de holandês em pastejo. Archivos de Zootecnia, v.54, p.63-74, 2005.

SNIFFEN, C.J.; O'CONNOR, J.D.; VAN SOEST, P.J. et al. A net carbohydrate and protein system for evaluating cattle diets. 2. Carbohydrate and protein availability. Journal of Animal Science, v.70, n.11, p.3562-3577, 1992.

SOUZA, S.R.M.B.O.; ÍTAVO, L.C.V.; RÍMOLI, J. et al. Comportamento ingestivo diurno de bovinos em confinamento 
e em pastagens. Archivos de Zootecnia, v.56, n.213, p.67-70, 2007.

UNIVERSIDADE FEDERAL DE VIÇOSA - UFV. Sistema de Análises Estatísticas e Genéticas - SAEG. Versão 8.0. Viçosa, MG, 2000. 142p.

VALADARES, R.F.D.; GONÇALVES, L.C.; RODRIGUEZ, N.M. et al. Níveis de proteína em dietas de bovinos. 1. Consumo e digestibilidades aparentes totais e parciais. Revista Brasileira de Zootecnia, v.26, p.1252-1258, 1997.

VAN SOEST, P.J. Nutritional ecology of the ruminant. 2.ed. Ithaca: Cornell, 1994. 476p.

WELCH, J.G. Rumination, particle size and passage from the rumen. Journal of Animal Science, v.54, n.4, p.885-894, 1982. 